\title{
MORTALITY AND SURVIVAL IN TRAUMATIC MYELOPATHY DURING NINETEEN YEARS, FROM 1946 TO 1965
}

\author{
By Roy H. Nyquist, M.D., and ERnest Bors, M.D. \\ Spinal Cord Injury Service, Veterans Administration Hospital, Long Beach, \\ California, and the Departments of Physical Medicine, and Rehabilitation, \\ and Surgery, University of California Medical School, Los Angeles, \\ California 90024
}

DURING the period from I April I946 to I April I965, 20I I patients have been treated on the Spinal Cord Injury Service, Veterans Administration Hospital, Long Beach, California. The total of deaths was 304. The total number of traumatic and non-traumatic surviving patients is 1707 . The total mortality was 15 per cent. The total number of deaths in non-traumatic paraplegia was 46 out of 160 or 29 per cent. The total number of deaths was 258 among I85I patients with traumatic myelopathy or 14 per cent. We found that 172 deaths were related (67 per cent.); 58 were non-related to the injury ( 22 per cent.); and 28 were undetermined (I I per cent.). Thus, I 72 related plus the 28 undetermined deaths account for 200 deaths. The corrected mortality figure, i.e. mortality from related and undetermined causes was 200 among I85 I patients or I I per cent. The cause of death was verified by autopsy in 99 instances ( 38 per cent.).

Percentage of Deaths according to Level and Extent of Lesion. The 258 deaths are divided according to neurological level and extent of the lesion into (I) cervical; (2) upper thoracic (TI to T6); (3) lower thoracic ( $\mathrm{T}_{7}$ to $\mathrm{T}_{\mathrm{I} 2}$ ); (4) lumbo-sacral; complete or incomplete lesions. When the neurological level was asymmetrical the higher dermatome level was chosen for purpose of classification (Table I).

\section{Relationship of Age Group to Survival (Tables II-V)}

Complete Cervical Deceased. The absolute figures of the minimum survival was from three days to 7.2 years. The maximum ranged from 0.8 years to 19.8 years. The average ranged from 0.8 years to 9.2 years (Table II). A decline of survival was observed in the age group above 50 years at injury as compared with that below 50 years.

Complete Cervical Living. The absolute figures of the minimum survival ranges from I to 3 years, the maximum from I to 2I years; the average ranges from I to I I 8 years (Table II). There is a decline of numbers of patients injured at the age of 50 years or more. Therefore, the average survival at present is more significant for those less than 50 years at time of injury.

Incomplete Cervical Deceased. The absolute figures of the minimum survival ranged from 2 days to 2.3 years, the maximum ranged from 0.2 to 18.7 years and the average from 0.2 to 8.5 years (Table II). There was a decline of survival 
TABLE I

Shows Subdivision of 258 Deaths in Traumatic Myelopathy according to Level and Extent of Lesion, from 4.I.46 To 4.I.65

\begin{tabular}{|c|c|c|c|c|c|}
\hline Level & Extent & \multicolumn{2}{|l|}{ Number } & \multicolumn{2}{|c|}{ Percentage } \\
\hline Cervical & $\begin{array}{l}\text { Complete } \\
\text { Incomplete }\end{array}$ & $\begin{array}{l}38 \\
32\end{array}$ & & $\begin{array}{l}(15 \%) \\
(13 \%)\end{array}$ & \\
\hline Thoracic I-6 & $\begin{array}{l}\text { Complete } \\
\text { Incomplete }\end{array}$ & $\begin{array}{r}\text { Sub-total } \\
\\
\\
36 \\
6\end{array}$ & (70) & $\begin{array}{r}(14 \%) \\
(2 \%)\end{array}$ & $(28 \%)$ \\
\hline Thoracic 7-I2 & $\begin{array}{l}\text { Complete } \\
\text { Incomplete }\end{array}$ & $\begin{array}{l}\text { Sub-total } \\
\quad \begin{array}{r}90 \\
20\end{array}\end{array}$ & & $\begin{array}{r}(35 \%) \\
(8 \%)\end{array}$ & $(16 \%)$ \\
\hline Lumbo-sacral . & $\begin{array}{l}\text { Complete } \\
\text { Incomplete }\end{array}$ & $\begin{array}{ll}\text { Sub-total } & \\
& \text { I7 } \\
& \text { I9 }\end{array}$ & (I IO) & $\begin{array}{l}(6 \%) \\
(7 \%)\end{array}$ & $(43 \%)$ \\
\hline & & Sub-total & (36) & & $(13 \%)$ \\
\hline & & Total 258 & & $100 \%$ & \\
\hline
\end{tabular}

TABLE II

Shows Average Survival Time in Years of Deceased and Living Patients with Complete and Incomplete Cervical Myelopathies according to Levels and Age-groups at time of Injury

\begin{tabular}{|c|c|c|c|c|c|c|c|c|}
\hline \multirow{3}{*}{$\begin{array}{l}\text { Age at } \\
\text { Injury }\end{array}$} & \multicolumn{4}{|c|}{ Complete Cervical } & \multicolumn{4}{|c|}{ Incomplete Cervical } \\
\hline & \multicolumn{2}{|c|}{ Deceased } & \multicolumn{2}{|c|}{ Living } & \multicolumn{2}{|c|}{ Deceased } & \multicolumn{2}{|c|}{ Living } \\
\hline & Number & Years & Number & Years & Number & Years & Number & Years \\
\hline I7-I9 & 3 & $8 \cdot 2$ & I7 & II 8 & 0 & 0 & I6 & $12 \cdot 6$ \\
\hline $20-29$ & 19 & $7 \cdot 5$ & IOI & II $\cdot 5$ & IO & $8 \cdot 5$ & I64 & I I $\cdot I$ \\
\hline $30-39$ & IO & $4 \cdot 5$ & 50 & $7 \cdot I$ & 8 & $3 \cdot 8$ & 72 & $8 \cdot 3$ \\
\hline $40-49$ & 2 & $9 \cdot 2$ & I5 & $7 \cdot 6$ & 4 & $7 \cdot 8$ & 29 & $5 \cdot 4$ \\
\hline $50-59$ & 3 & $3 \cdot 4$ & 2 & $3 \cdot 5$ & 4 & $7 \cdot 7$ & 12 & $7 \cdot 6$ \\
\hline $60-69$ & I & 0.8 & I & $I \cdot O$ & 5 & $2 \cdot 8$ & I3 & $5 \cdot 5$ \\
\hline $70+$ & o & 0 & 0 & 0 & I & $0 \cdot 2$ & 0 & 0 \\
\hline
\end{tabular}


after the age of 60 years as compared with the total of the younger groups, however, the number of patients was small.

Incomplete Cervical Living. The absolute figures of the minimum survival ranges from I to 2 years, the maximum from II to 23 years, and the average from 5.4 to 12.6 years (Table II). There was a decline in the numbers of patients

\section{TABLE III}

Shows Average Survival Time in Years of Deceased and Living Patients with Complete and Incomplete Upper Thoracic ( $\mathrm{TI}$ to $\mathrm{T} 6$, inclusive) Myelopathies according to Levels and Age-groups at Time of Injury

\begin{tabular}{|c|c|c|c|c|c|c|c|c|}
\hline \multirow{3}{*}{$\begin{array}{l}\text { Age at } \\
\text { Injury }\end{array}$} & \multicolumn{4}{|c|}{ Complete TI to 6} & \multicolumn{4}{|c|}{ Incomplete Ti to 6} \\
\hline & \multicolumn{2}{|c|}{ Deceased } & \multicolumn{2}{|c|}{ Living } & \multicolumn{2}{|c|}{ Deceased } & \multicolumn{2}{|c|}{ Living } \\
\hline & Number & Years & Number & Years & Number & Years & Number & Years \\
\hline I7-I9 & 4 & $12 \cdot 9$ & I6 & I $5 \cdot \mathrm{I}$ & 0 & 0 & 9 & $\mathrm{I} 4 \cdot \mathrm{I}$ \\
\hline $20-29$ & 22 & $9 \cdot 7$ & 125 & I $4 \cdot 6$ & 5 & 13.9 & $3 \mathrm{I}$ & $14 \cdot 7$ \\
\hline $30-39$ & 7 & $10 \cdot 5$ & 45 & 10.4 & I & $3 \cdot 9$ & I8 & $I 2 \cdot I$ \\
\hline $40-49$ & 2 & $10 \cdot 3$ & I I & $8 \cdot 3$ & 0 & 0 & 2 & $5 \cdot 5$ \\
\hline $50-59$ & 0 & 0 & 3 & I2 3 & 0 & 0 & 3 & $9 \cdot 7$ \\
\hline $60-69$ & I & $9 \cdot 0$ & 3 & $6 \cdot 3$ & 0 & 0 & I & $8 \cdot 0$ \\
\hline $70+$ & 0 & 0 & 0 & 0 & 0 & 0 & I & $6 \cdot 0$ \\
\hline
\end{tabular}

injured at the age of 40 years or more as compared with the number injured at the age below 40 years. At this time the average survival is higher in patients who were less than 40 years of age at time of injury.

Complete Thoracic I-6 Deceased. The absolute figures of the minimum survival ranged from $0 \cdot \mathrm{I}$ to $10 \cdot 2$ years, the maximum from 9 to $2 \mathrm{I} \cdot \mathrm{I}$ years and the average from 9 to 12.9 years (Table III). There was but one patient over the age of 60 years; he survived 9 years. All remaining patients were below 50 years at time of injury. No noticeable decline of survival was observed in the groups from 17 years to 50 years at time of injury.

Complete Thoracic I-6 Living. The absolute figures of the minimum survival ranges from I to Io years, the maximum from 8 to 23 years and the average from 6.3 to I 5.1 years (Table III). There is a decline of numbers of patients injured at the age of 40 years or more. At this time the average survival is higher for those injured at less than 30 years of age with the exception of three patients aged from 50 to 59 years at time of injury.

Incomplete Thoracic I-6 Deceased. The absolute figures of the minimum survival ranged from 0.8 to 3.9 years, the maximum from 3.9 to 26.4 years and 
the average from 3.9 to 12.9 years (Table III). Although none of the patients was past 40 years of age at time of injury a decline of the average survival time was noticed after the age of 30 years at time of injury.

Incomplete Thoracic I-6 Living. The absolute figures of the minimum survival ranges from I to 8 years, the maximum from 6 to 47 years and the average from

\section{TABLE IV}

Shows Average Survival Time in Years of Deceased and Living Patients with Complete and Incomplete Lower Thoracic ( $\mathrm{T}_{7}$ and $\mathrm{T}_{12}$, inclusive) Myelopathies according to Levels and Age-groups at Time of Injury

\begin{tabular}{|c|c|c|c|c|c|c|c|c|}
\hline \multirow{3}{*}{$\begin{array}{l}\text { Age at } \\
\text { Injury }\end{array}$} & \multicolumn{4}{|c|}{ Complete $\mathrm{T}_{7}$ to 12} & \multicolumn{4}{|c|}{ Incomplete $\mathrm{T}_{7}$ to $\mathrm{I} 2$} \\
\hline & \multicolumn{2}{|c|}{ Deceased } & \multicolumn{2}{|c|}{ Living } & \multicolumn{2}{|c|}{ Deceased } & \multicolumn{2}{|c|}{ Living } \\
\hline & Number & Years & Number & Years & Number & Years & Number & Years \\
\hline $17-19$ & 7 & I $7 \cdot \mathrm{I}$ & 34 & 14.6 & 4 & $2 \mathrm{I} \cdot 2$ & 8 & $17 \cdot 3$ \\
\hline $20-29$ & 48 & II $\cdot 2$ & 244 & $10 \cdot 8$ & 7 & $7 \cdot 7$ & 60 & 15.7 \\
\hline $30-39$ & I9 & 10.5 & I I 7 & II $\cdot 2$ & 4 & $6 \cdot 4$ & 26 & II 5 \\
\hline $40-49$ & 8 & $8 \cdot 8$ & 40 & $9 \cdot I$ & I & $7 \cdot \mathrm{I}$ & 13 & II $\cdot 5$ \\
\hline $50-59$ & 6 & $6 \cdot 6$ & 5 & $9 \cdot 6$ & 4 & $7 \cdot 5$ & 6 & $13 \cdot 3$ \\
\hline $60-69$ & 2 & $2 \cdot 8$ & I & I & 0 & 0 & 0 & 0 \\
\hline $70+$ & 0 & 0 & 0 & 0 & 0 & 0 & 0 & 0 \\
\hline
\end{tabular}

5.5 to 14.7 years (Table III). There are fewer patients who were injured at or past the age of 40 years as compared with the groups less than 40 years; at present the average survival is better at less than 40 years of age at time of injury.

Complete Thoracic 7-I2 Deceased. The absolute figures of the minimum survival ranged from 0.2 to 2.5 years, the maximum from 3.6 to 48 years and the average from $2 \cdot 8$ to I7.I years (Table IV). A decline of survival after 40 years of age at time of injury was noticed.

Complete Thoracic 7-12 Living. The absolute figures of the minimum survival ranges from I to 7 years, the maximum from to to $3 \mathrm{I}$ years and the average from II.5 to $17 \cdot 3$ years (Table IV). This high average survival pertains to all age groups although there are fewer patients who were injured at the age of 50 years or more.

Incomplete Thoracic 7-I2 Deceased. The absolute figures of the minimum survival ranged from I to $7 \cdot \mathrm{I}$ years, the maximum from $7 \cdot{ }^{\cdot}$ to 44.4 years and the average from $6 \cdot 4$ to $2 \mathrm{I} \cdot 2$ years (Table IV).

Incomplete Thoracic 7-12 Living. The absolute figures of the minimum survival ranges from I to 7 years, the maximum from Io to $3 \mathrm{I}$ years and the 
average from II 5 to $\mathrm{I} 7 \cdot 3$ years (Table IV). This high average survival pertains to all age groups although there are fewer patients who were injured at the age of 50 years or more.

Complete Lumbo-sacral Deceased. The absolute figures of the minimum survival ranged from $\mathrm{I} .9$ to 23 years, the maximum from 13.4 to 23 years and the average from 8.2 years to 23 years (Table V). It should be stressed that the entire group was small and the figure of 23 years pertains to one patient. There was no noticeable decline connected with the age groups.

Complete Lumbo-sacral Living. The absolute figures of the minimum survival ranges from I to II years, the maximum from II to 25 years and the average from I I to $\mathrm{I} 6 \cdot 3$ years (Table V). There is a consistent slight drop of average survival with each passing decade, from the second through the fifth, with only one patient in the sixth decade.

Incomplete Lumbo-sacral Deceased. The absolute figures of the minimum survival ranged from 0.7 to 5.7 years, the maximum from 5.7 to 20.2 years and the average from 5.7 to $\mathrm{I} 2$ years (Table V). There was one patient who was past 70 years at the time of injury and who survived for 5.7 years. In view of the small number of cases no statement as to trend is appropriate.

Incomplete Lumbo-sacral Living. The absolute figures of the minimum survival ranges from I to I 7 years, the maximum from I9 to 23 years and the average from 7 to $19 \cdot 3$ years (Table V). The average survival is higher than in all patients with other levels of lesions. Here, too, there seems to be a slight drop of the average survival with each passing decade.

\section{SuRvival Time}

Among the 1593 patients now living with traumatic spinal cord lesions were I 32 from our original group of I 80 patients of World War II who have survived 20 years or more as follows:

$\begin{array}{rrrrrr}\text { from I942 } & \cdot & \cdot & \cdot & \cdot & 3 \\ \text { from I943 } & \cdot & \cdot & \cdot & \cdot & 42 \\ \text { from I944 } & \cdot & \cdot & \cdot & \cdot & 52 \\ \text { from I945 } & \cdot & \cdot & \cdot & \cdot & 73 \\ & & & \text { Total } & \cdot \text { I32 }\end{array}$

Therefore, slightly over 73 per cent. of our original group of 180 have survived their injury over 20 years.

The survival time of 20 or more years is presented for the entire group of I 593 living patients with traumatic spinal cord lesion in Table VI, which demonstrates the number of patients surviving 20 or more years to be greater with lesions below the cervical cord segments. Approximately one-fourth of patients with thoracic and lumbo-sacral lesions have survived 20 years or more. The majority of these patients were less than 40 years of age at the time of injury. 
The survival time of Io to I9 years is presented for the entire group of I 593 living patients in Table VII, which also demonstrates the increase in survival time with descent of the level of injury. Here again the majority of patients was less than 40 years of age at time of injury.

\section{TABLE V}

Shows the Average Survival Time in Years of Deceased and Living Patients with Complete and Incomplete Lumbo-sacral Myelopathies according to Levels and Age-groups at Time of Injury

\begin{tabular}{|c|c|c|c|c|c|c|c|c|}
\hline \multirow{3}{*}{$\begin{array}{l}\text { Age at } \\
\text { Injury }\end{array}$} & \multicolumn{4}{|c|}{ Complete Lumbo-sacral } & \multicolumn{4}{|c|}{ Incomplete Lumbo-sacral } \\
\hline & \multicolumn{2}{|c|}{ Deceased } & \multicolumn{2}{|c|}{ Living } & \multicolumn{2}{|c|}{ Deceased } & \multicolumn{2}{|c|}{ Living } \\
\hline & Number & Years & Number & Years & Number & Years & Number & Years \\
\hline I7-I9 & 2 & $9 \cdot 6$ & 8 & $16 \cdot 3$ & 2 & $8 \cdot 0$ & 3 & $19 \cdot 3$ \\
\hline $20-29$ & 6 & $8 \cdot 2$ & 65 & 13.9 & 7 & I2 $\cdot 0$ & IO4 & $16 \cdot 2$ \\
\hline $30-39$ & 8 & IO.I & $3^{8}$ & II 3 & 7 & $9 \cdot 6$ & 33 & I $3 \cdot 2$ \\
\hline $40-49$ & I & $23 \cdot 0$ & 12 & $7 \cdot 6$ & 2 & $7 \cdot 8$ & I3 & $7 \cdot 0$ \\
\hline $50-59$ & 0 & 0 & I & II $\cdot 0$ & 0 & 0 & 2 & 10.5 \\
\hline $60-69$ & 0 & 0 & 0 & 0 & 0 & 0 & 0 & 0 \\
\hline $70+$ & 0 & 0 & 0 & 0 & I & $5 \cdot 7$ & 0 & 0 \\
\hline
\end{tabular}

\section{TABLE VI}

Shows the Number of Patients surviving Twenty or more Years after Date of Injury to the Spinal Cord at the Various Levels. Note the Increase in Percentage at the Lower Levels. $3 \mathrm{I} .5$ per cent. of the Living Patients with Thoracic and Lumbo-sacral Lesions have survived 20 Years or more

\begin{tabular}{|c|c|c|}
\hline Level & $\begin{array}{l}\text { Number surviving } \\
20 \text { or more years }\end{array}$ & $\begin{array}{c}\text { Number of living } \\
\text { Patients }\end{array}$ \\
\hline Cervical complete & I3 $(6.9 \%)$ & I86 \\
\hline Cervical incomplete & $18(5.8 \%)$ & 306 \\
\hline Thoracic I-6, complete & $51(25 \cdot 1 \%)$ & 203 \\
\hline Thoracic I-6, incomplete & I5 $(23.0 \%)$ & 65 \\
\hline Thoracic 7-I2, complete & II $4(25 \cdot 8 \%)$ & $44 \mathrm{I}$ \\
\hline Thoracic $7-12$, incomplete & $36(3 \mathrm{I} \cdot 8 \%)$ & II3 \\
\hline Lumbo-sacral, complete & $33(26 \cdot 6 \%)$ & I 24 \\
\hline Lumba-sacral, incomplete & $59(38 \cdot 0 \%)$ & I 55 \\
\hline Total & $339(2 \mathrm{I} \cdot 2 \%)$ & I 593 \\
\hline
\end{tabular}




\section{TABLE VII}

Shows the Number of Living Patients who have survived Io to I9 Years since onset of Traumatic Myelopathy. Note the Increase in Percentage Concurrent with the Descent of the Level of Injury. The Majority of this Io to I9 year Survival Group of Patients was less than 40 Years of Age at Time of Injury

\begin{tabular}{|c|c|c|}
\hline Level & $\begin{array}{l}\text { Number surviving } \\
\text { Io to I } 9 \text { years }\end{array}$ & $\begin{array}{c}\text { Number of Living } \\
\text { patients }\end{array}$ \\
\hline Cervical complete & $89(47 \cdot 6 \%)$ & I86 \\
\hline Cervical incomplete . & I $4 \mathrm{I}(46 \cdot \mathrm{I} \%)$ & 306 \\
\hline Thoracic I-6, complete & $139(68 \cdot 5 \%)$ & 203 \\
\hline Thoracic $\mathrm{I}-6$, incomplete & $44(67 \cdot 7 \%)$ & 65 \\
\hline Thoracic 7-I2, complete & $310(70 \cdot 3 \%)$ & $44 \mathrm{I}$ \\
\hline Thoracic 7-12, incomplete & $86(76 \cdot \mathrm{I} \%)$ & II 3 \\
\hline Lumbo-sacral, complete & $76(6 \mathrm{I} \cdot 3 \%)$ & I 24 \\
\hline Lumbo-sacral, incomplete & I I $7(75 \cdot 5 \%)$ & I55 \\
\hline Total & $1002(62 \cdot 9 \%)$ & I593 \\
\hline
\end{tabular}

Renal Causes of Death. Renal failure was the cause of death in 85 out of 258 deaths $(32.9$ per cent.). Renal death occurred in 5 per cent. of all patients with traumatic myelopathy as shown in Table VIII. Renal failure was accompanied by secondary amyloidosis in 13 patients and by renal hypertension in seven patients $(8.2$ per cent.). Renal failure is a cause of death related to the cord injury.

On analysing Table VIII several points are of interest:

I. The peak of mortality percentage falls within the second five-year period following injury, with the exception of the lumbo-sacral group which reaches the peak in the third five-year period.

2. Renal death occurred in 7 per cent. of patients with lower thoracic levels ( $\mathrm{T}_{7}$ to $\mathrm{I}_{2}$ ); in 6 per cent. with upper thoracic levels ( $\mathrm{T}_{\mathrm{I}}$ to 6 ); and was equal 3 per cent. in patients with cervical and lumbo-sacral levels.

3. Our figures suggest that if a patient survives I 5 years without serious renal complications, the probability of death from renal failure declines. This is evident in the subtotal at the bottom of Table VIII of 3 per cent. for the 16 to 20 year survival group and also in the subtotal of I per cent. for the $2 \mathrm{I}+$ years survival group.

Secondary Amyloidosis. Death from secondary amyloidosis was diagnosed in 24 instances of 99 necropsies $(24.2$ per cent.). However, it was only 9.6 per cent. in our total deaths of 258 because only 38 per cent. of the dead were examined post mortem. Death from secondary amyloidosis occurred in I. 5 per cent. of all patients with traumatic myelopathy.

The group of 24 with amyloidosis consisted of two sub-groups, I I patients 
with amyloidosis and 13 with amyloidosis plus uraemia. Thus, an overlap exists because these I3 patients are also listed under the heading of renal death. The II patients with amyloidosis had also renal involvement but did not die clinically from kidney failure. Obviously, not included are those patients whose cause of death was undetermined, accidental or suicidal, which totalled an additional 62 patients; if we presume that some may have had amyloidosis at the ratio shown above, on necropsy ( 24.2 per cent.). perhaps I6 of the 62 patients could be added to our figure. This would increase the incidence of amyloidosis to about 15 per cent. The total incidence of amyloidosis in I85I traumatic myelopathy patients, living and dead, can then be estimated as about 2 per cent.

The incidence of secondary amyloidosis was as follows: cervical lesions2 patients; thoracic I-6 lesions -8 patients; thoracic 7-I2 lesions-I4 patients; lumbo-sacral lesions-I patient. This incidence by levels is not too dissimilar from that of deaths from renal failure. Inasmuch as amyloidosis is due to decubitus ulcers in an overwhelming majority, the correlation between level and the incidence of amyloidosis can be traced as maximum to those groups of patients who have, as mentioned above, the greatest incidence of decubitus ulcers; these are the patient with thoracic cord lesions.

The survival time of patients with amyloidosis was as follows: in the first five-year period-five deaths; in the second five-year period-nine deaths; in the

\section{TABLE VIII}

\section{Survival (in years)}

Shows the Number and Percentage of Renal Mortality and the Number of Patients surviving according to Levels of Traumatic Myelopathy and Length of Survival

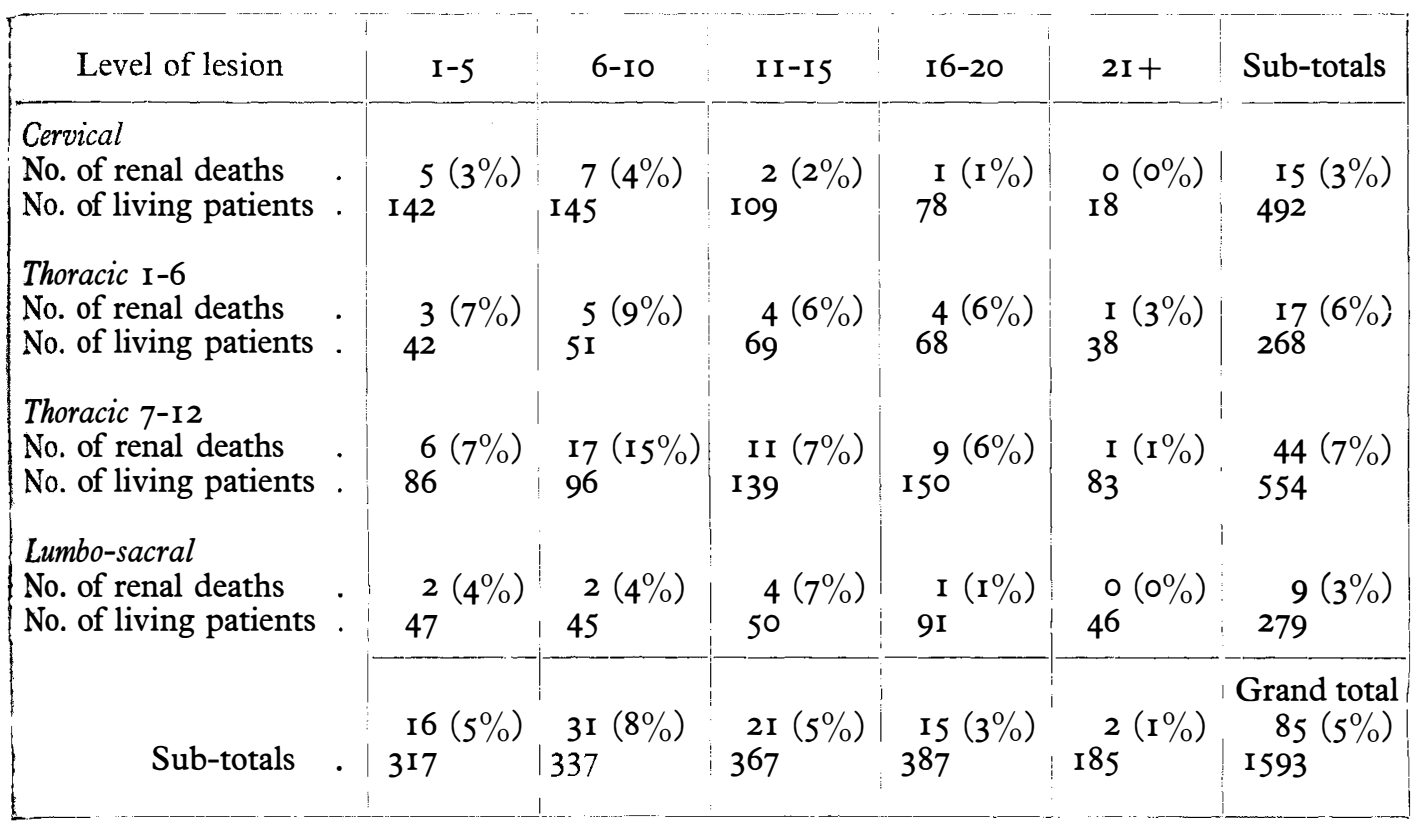


third five-year period-five deaths; in the fourth five-year period-four deaths; and in the fifth five-year period-one death.

The survival time of patients with secondary amyloidosis is similar to that of patients with renal failure; this is not surprising because slightly more than half of these patients died primarily of uraemia.

Pulmonary Deaths. Pulmonary complications caused I 8 of the 258 deaths (6.9 per cent.) or 0.9 per cent. of all I85I traumatic patients. Fif teen deaths were caused by pneumonia, one by pulmonary tuberculosis, one by Asiatic influenza and one was a post-operative surgical death from respiratory failure.

Thirteen patients had cervical cord lesions $(72 \cdot 2$ per cent.). Of these 13 patients, Io had complete and 3 had incomplete lesions. The remaining 5 patients had lesions between $\mathrm{T}_{7}$ and $\mathrm{L}_{1}$, of which 3 had complete and 2 had incomplete lesions.

The age of the 13 patients with cervical cord lesions ranged from 20 to 56 years at time of injury. Only one patient died of pneumonia within 45 days after trauma; all others in this group lived from Io months to I I years.

The age of the 5 patients with other than cervical cord lesions ranged from 2 I to 42 years at the time of injury and they survived from I to 12 years.

Pulmonary deaths do not include the acute respiratory failure in direct connection with immediate ascending post-traumatic pathologic changes of cord and meninges; these will be considered under the heading of bulbar involvement.

Of the 18 deaths from pulmonary causes, 13 are directly related to the injury, in that these patients had a reduced breathing ability as is known to exist in patients with cervical cord lesions (Hemmingway et al., 1958). Of the remaining five patients with thoracic or lumbar lesions, three are believed to have occurred in relation to the injury; two had lesions at $\mathrm{T}_{7}$ and $\mathrm{T}_{9}$ respectively and, therefore, had a reduced abdominal muscle innervation; the last with a lesion at $\mathrm{L}_{\mathrm{I}}$ had post-operative respiratory failure. Two of the five patients died of causes considered to be unrelated to the injury; one of tuberculosis and the other of lobar pneumonia, and their levels were TII and TI2 respectively.

Suicidal Deaths. Suicidal death occurred in $2 \mathrm{I}$ or $\mathrm{I} \cdot 3$ per cent. of all patients with traumatic myelopathy, but in $8 \cdot \mathrm{I}$ per cent. of 258 deaths. The incidence was almost equally distributed among all levels of injury.

With the exception of one patient who was past 40 years of age at the time of injury, the majority of 13 patients was below 29 years of age and the remaining seven patients were 30 to 39 years of age at the time of injury.

Three patients committed suicide within one year after injury, including one tetraplegic. Six patients died from 2 to 5 years following injury, including one tetraplegic. Seven died from 6 to to years after injury, including a third tetraplegic. Five patients died from I I to 15 years after injury, including 2 tetraplegics. One patient died I 8 years after injury.

The age at time of death was more than 30 years in 16 patients, including three patients between $4 \mathrm{I}$ and 50 years of age and two patients who were older than 50. The remaining five patients were between 24 and 29 years old at the time of death.

Eleven patients died from over-dosages of drugs, including two tetraplegics; five died from gunshot wounds; two tetraplegics from knife wounds; one tetra- 
plegic from plastic bag asphyxia; one patient hanged himself; and another patient drove his car over a cliff.

Vascular Deaths. A large group of conditions was included under this heading; cardiac deaths, cerebrovascular deaths, deaths from pulmonary embolism, generalised arteriosclerosis, ruptured aneurysms, haemorrhage of decubitus ulcer and bacterial endocarditis. Renal hypertensive disease was listed under renal death since it was associated with renal failure as the primary cause of death.

Vascular conditions caused 49 of 258 (I9 per cent.) deaths, or almost 3 per cent. of the I85I patients with traumatic lesions. Of these deaths I5 $(30.6 \mathrm{per}$ cent.) were thought to be related, and $34(69.4$ per cent.) were considered unrelated to the injury.

In the following, deaths related to the injury will be primarily considered: There were two patients with cardiac deaths; one early death was within I9 days following a $\mathrm{C}_{3}$ injury with consecutive cardiac and respiratory failure in spite of an artificial respirator. The other late death occurred almost I8 years after injury due to coronary occlusion. The latter patient had hypertensive disease treated during the last seven years, and developed a bladder cancer; the carcinoma could not be treated surgically because of the many recurrent attacks of coronary occlusion; the hypertension was thought to be of renal origin.

The only cerebrovascular deaths related to the injury were those of autonomic dysreflexia; they occurred in four patients with cervical injuries, three of which were incomplete at $\mathrm{C}_{3}$ to $\mathrm{C}_{7}$ levels and one was complete at C6. These patients survived the injury from I to I 5 years. They were from 25 to 49 years of age at time of injury. The survival time did not depend upon the age at injury, as one patient aged 28 years survived only I year, while another aged 47 years survived I5 years.

There were six deaths from pulmonary embolism; this means 2.3 per cent. of all deaths or 0.3 per cent. of all traumatic paraplegics. Three patients died within I to 2 months following injury; the remaining three patients died from 7.5 to 20 years after injury. The age at injury of those who died within 2 months ranged from 28 to 38 years; the age of those who died late ranged from 24 to 28 at time of injury, and from $3 \mathrm{I}$ to 49 at time of death. The levels of those patients who died early were $\mathrm{C}_{5}$-incomplete, $\mathrm{T}_{4}$-complete, and $\mathrm{T}_{\text {-co-complete; while }}$ the levels of those who died late were T5-complete, T8-complete and Tiocomplete.

One patient died from haemorrhage of a decubitus ulcer I2 years after injury.

Within the deaths not related to the injury one fact was impressive, namely the age of those five patients who died from arteriosclerotic causes. With the exception of one patient who died at the age of 43, I4 years after an incomplete lesion at $\mathrm{LI}_{\mathrm{I}}$, the remaining four patients were between 58 and 67 and survived the injury for from Io months to 16 years. Their injuries were in two instances at $\mathrm{C} 6$, in one at $\mathrm{T}_{4}$ and in the remaining patient at $\mathrm{T}_{\mathbf{2} 2}$.

Deaths from cardiovascular causes, including coronary heart disease, occurred in 23 patients; this means almost 47 per cent. of vascular deaths, 8.9 per cent. of all deaths or $\mathrm{I} \cdot 2$ per cent. of all traumatic paraplegics. With the exception of one all other deaths were considered unrelated to the injury. The lifespan after injury ranged from a minimum of 3 months (in a patient injured at the age of 76 ) to a maximum of 45 years (in a patient injured at the age of 19 years). There were 
Io patients who lived less than 20 years and the remaining I 3 patients lived more than 20 years.

Four patients had incomplete cervical lesions, three of whom were older than 50 at the time of injury, who survived 3 months to I 8 years, and one who was 32 and survived 6 years.

Of I3 patients with thoracic (complete or incomplete) lesions, 6 were below the age of 30 at the time of injury and they survived from 18 to 45 years. Two patients, aged 30 and 32, survived 12 and 4 years, respectively. Five patients aged between $4 \mathrm{I}$ and 6I years at time of injury survived for 3 to I7 years; generally the younger patients survived longer.

Of 6 patients with lumbar (complete or incomplete lesions) 5 were between 31 and 38 years of age at time of injury and survived from 6 to 18 years; one was 72 at time of injury and survived 6 years; again the younger ones survived longer.

According to age-groups at time of death the majority of patients was in the fifth decade. Following the fifth decade the actual number of patients decreased which explains the relatively small number of deaths past the fifth decade. Per contra, considering the large number of patients in the age groups below 40, the cardiovascular death rate was relatively low in that group.

Cerebrovascular accidents (other than those caused by autonomic dysreflexia) occurred in 4 patients between the age of 33 and 66. Their lesions were at C4-incomplete, T9-complete, Tro-incomplete, and Tir-complete. The survival time ranged from I to 48 years. Two patients died of typical strokes, a third from the rupture of a cerebral aneurysm and the fourth of a subarachnoid haemorrhage associated with hypertensive encephalopathy. The latter two patients were in their fourth decade at time of death and had survived 15 and 6 years, respectively. Both had thoracic lesions.

Three patients had ruptured aortic aneurysms; one sustained it with the trauma to the chest in a car accident several years after the onset of his paraplegia; another developed an aortic aneurysm as a sequel of the same gunshot wound which rendered him paraplegic; the third developed an aneurysm of the aortic arch which ruptured spontaneously, entirely unrelated to his injury. All patients were between 20 and 30 at time of spinal cord injury and their survival time ranged from 8 to 32 years. Two patients had complete thoracic lesions ( $\left.\mathrm{T}_{5}, \mathrm{~T}_{9}\right)$ and one had a $\mathrm{L}_{3}$ complete lesion.

One patient with a complete lesion at T6 died of subacute bacterial endocarditis; he was injured at the age of 30 and died 8 months later; this death was considered unrelated to the spinal cord injury.

One patient died from essential, not renal, hypertensive disease. He was 35 years of age at time of injury, which was at LI incomplete, and he survived for 7 years; his death was thought to be unrelated to the cord injury.

Neoplasia. Death from neoplasia occurred in 16 out of 258 deaths $(6 \cdot 2$ per cent.); it occurred in 0.99 per cent. of all patients with traumatic myelopathy. Until I960 few deaths from neoplasia were recorded. The majority occurred in the last 5 years. In this connection it should be noted that the bulk of our hospitalised patients is in the age group from 30 to 50 years.

Cancer of the urinary tract caused death of 7 patients; one with renal clear cell carcinoma, 5 with bladder carcinoma and one with urethral carcinoma. Cancer of a sacral decubitus ulcer caused death in one patient. Two cases of adeno- 
carcinoma of the stomach, two cases of leukaemia, two of bronchogenic carcinoma, one with primary liver carcinoma, one with cerebral astrocytoma accounted for death in the remaining eight patients.

The peak mortality, 9 patients, was in the fifth decade ( 56 per cent.); 3 patients (I8.7 per cent.) were in the fourth decade; 2 patients (12.5 per cent.) were in the sixth decade; one patient was in the eighth decade $(6 \cdot 2$ per cent.).

No correlation could be found between neoplasial deaths and the level or extent of the lesions.

If we presume that deaths from neoplasias other than those of the urinary tract or decubitus ulcers are unrelated to the injury (such as stomach, lung, brain, liver and blood), we find that 50 per cent. belonged to the unrelated and the other 50 per cent. belonged to the related group.

Cardio-respiratory Death from Bulbar Involvement. There were six patients in this group, 2.3 per cent. of the 258 deaths, or 0.32 per cent. of 185I traumatic patients. In three patients, autopsy findings confirmed the clinical diagnosis of ascending oedema involving the medulla ablongata. Four patients had complete lesions ( $\mathrm{C}_{3}, \mathrm{C}_{4}$, and $\mathrm{T}_{2}$ ), and two had incomplete lesions at $\mathrm{C}_{5}$ and $\mathrm{C} 6$ respectively.

Four of these six patients had a short life span following injury of from 2 to I9 days. One of them with a $\mathrm{C}_{3}$ complete lesion lived 19 days with the aid of an artificial respirator. Their respective ages at time of injury ranged from 23 to 62 years.

Two patients died after longer periods following cord injury; namely, 4I days and almost 20 years. The former case concerned a patient aged 23 years at time of his T2 complete injury. His final clinical picture showed peripheral vascular collapse preceded by an emotional outburst; autopsy demonstrated bulbar and cerebral oedema. The latter patient was 23 years at time of injury which was $\mathrm{C}_{4}$ complete. He showed the clinical picture of ascending arachnoiditis, myelomalacia and bulbar involvement, confirmed at autopsy almost 20 years after trauma.

The deaths of all six patients must be considered to be related to the spinal cord injury.

Accidental Deaths. Accidental death occurred in $\mathrm{I} 2$ patients, 4.6 per cent. of the 258 deaths or 0.64 per cent. of I85I patients with traumatic cord lesions. Car accidents were the cause of death in 9 patients (75 per cent.).

In one instance a patient with a cervical lesion sustained a skull fracture with cerebral haemorrhage when kicked by a bucking horse which jumped the fence at a rodeao which he watched as a spectator. Another patient with a TIO complete lesion was struck by a wheel which flew off a racing car and descended into the spectators. A third patient with a Tro complete lesion drowned in a motorboat accident.

With the exception of one car accident and the drowning accident no suspicion was raised as to potential suicide, and even in these two instances suicidal intention could not be proven.

The levels of these patients ranged as follows: four had cervical lesions, one had an upper thoracic lesion and the remaining seven had lower thoracic lesions.

The age at injury ranged from 18 to 28 years. The age at death ranged from 23 to 49 years. The survival time ranged from I to $3 \mathrm{I}$ years. 
We considered only the death of the patient injured by the kicking horse to be related to the injury since he was a tetraplegic and unable to move his wheelchair quickly enough to avoid the pounding hoof.

Iatrogenic Causes. Eight patients died due to difficulties of diagnosis or therapy of abdominal conditions, i.e. 3.4 per cent. of 258 deaths or 0.48 per cent. of I85I traumatic paraplegics. In the majority, these difficulties were precipitated by the nature of the spinal cord injury and its resulting neurological deficit. Thus in 5 of the 8 patients the diagnosis of a perforated viscus was missed and the patients succumbed to the ensuing peritonitis. In the remaining 3 patients surgical procedures did not prevent death.

In view of the importance of these observations a detailed account is given as follows:

I. A 30-year-old patient with a complete lesion at $\mathrm{C}_{5}$ was transferred from another hospital. He had diarrhoea, vomiting and shoulder pain which were not interpreted as peritonitis but chronic ileus was diagnosed in the absence of free air in the abdomen. Autopsy showed a perforated tubercular appendicitis with peritonitis to which he succumbed within two months.

2. A 43-year-old patient with an incomplete lesion at C6 and with cerebral concussion and contusion was transferred from another hospital in a cachectic and disoriented condition. Two months prior to his car accident he had repair of a perforated gastric ulcer. Communication with the patient was nigh impossible. No suspicion existed regarding an abdominal complication but severe spasticity was observed. Temperature, pulse, and respiration were normal two hours prior to death which occurred six days after admission and four months after the car accident. Peritonitis and gangrene of small bowel were found.

3. A 25-year-old patient with an incomplete lesion at $\mathrm{T}_{7}$ was originally treated at our hospital; he died almost I9 years after his injury when last readmitted for treatment of renal hypertension and cardiac insufficiency with pulmonary oedema. Because of signs suggestive of partial bowel obstruction a sigmoidoscopy was done following which he developed left upper quadrant and left shoulder discomfort, and went into peripheral vascular collapse. Free air was seen in the abdominal cavity and a laparotomy was performed. In addition to an old pelvic abscess a small perforation of the lower colon was found and closed. The operative area was drained. In spite of these procedures the patient died within I 2 hours post-operatively. Autopsy showed ruptured colonic diverticulum and peritonitis.

4. A 20-year-old patient with a complete lesion at $\mathrm{T}_{7}$, formerly known to us, died in transfer from another hospital where his symptoms and signs were not interpreted as peritonitis, which proved to be the cause of death, precipitated by perforation of the appendix, diagnosed at autopsy. He survived his injury by $4 \cdot 25$ years; the onset of the appendicitis predated his death only by a short period of time.

5. A patient aged 24 at time of injury, with a complete lesion at $\mathrm{T} 8$, died at our hospital I $2 \frac{1}{2}$ years later. Five years prior to his death he had a ruptured sigmoid diverticulum which was diagnosed and treated by sigmoid colostomy which was closed after I4 months. Six months after closure, a new perforation of the sigmoid was treated by transverse colostomy. Eleven months later intestinal obstruction had to be released by removing adhesions and resection of a large Meckel's diverticulum. Two years later both loops of the double barrel colostomy were anastomosed to the skin. Eight months later he developed again intestinal 
obstruction; on laparotomy a third sigmoid perforation was found and closed. Following this procedure he developed convulsions followed by peripheral vascular collapse to which he succumbed within 24 hours. Autopsy disclosed general peritonitis.

6. A 19-year-old patient at time of his injury, incomplete at $\mathrm{T} 8$, died $3^{\frac{1}{2}}$ years later. Although perforation of a hollow viscus was suspected, exact localisation was impossible and the surgeons felt exploration was contra-indicated because of the poor general condition. He succumbed 2 weeks after onset of his symptoms; necropsy showed perforated jejunal ulcer with peritonitis. Repeated gastro-intestinal and gall-bladder examinations, done prior to his last illness had been consistently negative.

7. A 30 -year-old patient was injured $2 \frac{3}{4}$ years prior to death sustaining a complete lesion at L2. A left nephrolithotomy led to a perinephritic abscess, later to retroperitoneal haemorrhage, thrombosis of the vena cava, paralytic ileus and peritonitis. This clinical diagnosis was confirmed by necropsy.

8. A 53-year-old patient with an incomplete C6 lesion survived $2 \frac{1}{3}$ years. Gastrointestinal examination showed a large, chronic, penetrating bleeding gastric lesion, suspected to be malignant; therefore, a total gastrectomy was performed; the histopathological diagnosis was benign gastric ulcer; the patient died 8 months later of inanition in spite of all therapeutic efforts.

Hepatic Deaths. Six patients died of liver disease other than neoplasm, i.e. 2.3 per cent. of 258 deaths or 0.23 per cent. of $185 \mathrm{I}$ traumatic paraplegics. All of these deaths were considered to be related to the injury.

The ages ranged from I 8 to 37 years, the survival time from 4 months to 6.8 years. The lesions were at the following levels: $\mathrm{C} 8$ complete (one); $\mathrm{T}_{7}$ complete (one); TI2 complete (two); L3 complete (one); and $\mathrm{L}_{4}$ incomplete (one).

Two patients ( $\mathrm{T}_{12}$ complete) died of cirrhosis; three patients ( $\mathrm{T}_{7}$ complete, L3 complete, L4 incomplete) died of acute hepatitis following blood transfusions. This condition was diagnosed as homologous serum hepatitis in two patients and as viral hepatitis with acute liver atrophy in the third. The sixth patient in this group died of acute hepatitis caused by Thorazine (chlorpromazine).

Deaths from Miscellaneous Causes. These included four patients (i.e. I.55 per cent. of 258 deaths or $0.2 \mathrm{I}$ per cent. of I85I traumatic paraplegics) whose ages ranged from 32 to 55 years, and whose survival time was $2 \cdot 4$ to II 2 years. The levels were $\mathrm{C}_{5}$ complete (two), TII complete (one) and TI2 incomplete (one).

Two patients died from meningitis and abscess; one ( 55 complete) developed a cerebral abscess, the aetiology of which remained undetermined; he survived II years; the other succumbed to a meningitis secondary to an epidural abscess from shell fragment which perforated into the sub-thecal space $3 \frac{3}{4}$ years after his original injury which was incomplete at TI2.

A third patient (C5 complete) died following a convulsive episode precipitated by an intracaine reaction $2 \frac{1}{2}$ years after injury.

A fourth patient (TII complete) died of progressive muscular atrophy seven years after his original cord trauma.

Three of the four deaths were considered to be related to the injury; the exception was the one with progressive muscular atrophy. 
Deaths from Undetermined Causes. Twenty-eight patients (i.e. I0.85 per cent. of 258 deaths or I 47 per cent. of I $85 \mathrm{I}$ paraplegic patients) belonged into this group. Their ages at injury ranged from ig to 65 years and their survival time ranged from I 33 to 2 I years. There were 8 patients with cervical lesions, of which 4 lesions were incomplete; ro patients had complete, and 3 patients had incomplete thoracic lesions; of the remaining 7 patients, 5 had incomplete and 2 patients had complete lumbar lesions.

We suspect that among these 28 patients 7 may have hastened if not actually accomplished their deaths with drug addiction and alcoholism.

Two additional patients were known to us to have had diabetes and aortic aneurysm, respectively.

\section{DISCUSSION}

Related and Non-related Deaths. Among 20 I p patients with traumatic and non-traumatic spinal cord and/or cauda equina lesions the total mortality was I5 per cent. This is 4 per cent. higher than Guttmann's figure on 3000 patients (1964). The mortality in our non-traumatic patients (29 per cent.) was more than twice as much as in our traumatic paraplegic patients (I4 per cent.), similar to the experience of Barber and Cross (1952). Neither poliomyelitis nor myelodysplasia patients, with a relatively good survival rate, are treated at this Spinal Cord Injury Centre which makes our non-traumatic mortality rate worse than that of Guttmann (1962). Among the 258 deaths in traumatic paraplegia, I72 (67 per cent.) were related to the injury, 58 ( 22 per cent.) were unrelated, and 28 (I I per cent.) were of undetermined cause. There is an increase of the related cases with the passage of years. In 1954 there were only 60 per cent. related cases (Bors, I954). If one corrects the mortality rate of I4 per cent. in our I85I traumatic patients by subtracting the number of 58 deaths unrelated to the injury from the total number of 258 deaths, one arrives at a figure of 10.8 per cent.; if a further correction were made by subtracting the 28 deaths of undetermined cause, this figure would decline to 9.3 per cent. Both figures are close to the mortality rate of I I.5 per cent. reported by Guttmann (I962) in a comparable number of 1658 traumatic paraplegic patients. No lower mortality figures have recently been reported (Dick, I952; Damanski, 1956; Lord \& Bunts, I956; Burke et al., 1960; Breithaupt et al., I96I), except by Barber and Cross (I952) over a short post-traumatic period.

If one accepts Tribe's (I963) suggestion that 'early' death is defined as occurring within the first two months after injury, we had ten patients $(3.8$ per cent.) in this category. This is less than others have reported (Hardy, 1956: 10.9 per cent.; Burke et al., I960: 5-30 per cent.; Tribe, I963: I8 per cent.; Gibbon et al., I965: 8 per cent.) and far less than in World War I when 6I per cent. (Cook, 1942) of the patients died within the first two months. The reason for our low figure is the fact that we receive relatively few patients within the first two months as do the Spinal Cord Injury Units in the British Isles. The cause of death within the first two months was pulmonary embolism in 4 patients, a not unusual occurrence (Tribe, I963); progression of oedema to the medulla oblongata with cardio-respiratory failure in 5 patients; bronchopneumonia in one; and tuberculous peritonitis in another. The majority of all these patients had complete cervical cord lesions. 
Dick (I952) reported no deaths in patients with incomplete lesions. In this study $70 \cdot 2$ per cent. of the 258 deaths were in patients with complete lesions and 29.8 per cent. in those with incomplete lesions. This ratio is different for the I593 living patients, namely 954 ( 59.8 per cent.) with complete lesions versus 639 (40.2 per cent.) with incomplete lesions, reflecting the better survival of patients with incomplete lesions.

Role of Age. In studying Tables II through $\mathrm{V}$ one finds that patients under 40 years of age at time of injury and with lower levels of lesions have a better longevity than older patients with higher lesions. This is due not only to decline of life expectancy in general, but also to reduced body resistance, insufficient to cope with the sequelae of injury. Similar observations have been made by others (Partsch \& Wagner, 1949; Dick, 1952; Burke et al., 1960; Talbot, I962). In evaluating the role of age at time of injury among the deceased, our figures suggest that age was of importance for the average survival of patients with complete and incomplete cervical, incomplete upper thoracic ( $\mathrm{T}$ I to T6), and complete lower thoracic ( $\mathrm{T}_{7}$ to $\mathrm{T}_{12}$ ) lesions. The younger the patient was at time of injury the longer was the survival. What is amazing is that the same did not apply to the remaining patients with complete upper thoracic (TI to T6), incomplete lower thoracic ( $\mathrm{T}_{7}$ to $\mathrm{T}_{12}$ ) and with complete or incomplete lumbosacral lesions. No explanation is offered beyond the thought that the age factor in these latter groups was not necessarily directly related to the patient's demise. The incidence of injury is greater in patients 17 to 40 years of age at time of injury than in those over 40 years of age, i.e., during the most active years of life. The level of trauma is in the following order of frequency: I. lower thoracic, 2. cervical, 3. lumbo-sacral, and 4. upper thoracic. This is compatible with the 'weak spots' in the lower thoracic and lower cervical portions of the vertebral column.

Survival Time. I38I out of I 593 living patients ( 86.6 per cent.) have survived over Io years (Tables VI, VII). I002 (62.9 per cent.) out of the I38I have survived from Io to I9 years; the remainder of 379 (23.8 per cent.) have survived 20 or more years. This drop of survival from the second to the third decade is perhaps explained by the increase of renal deaths 5-I 5 years after injury (Nyquist, I960), to be discussed further. In confirmation of the literature (Partsch \& Wagner, I949; Burke et al., 1960; Talbot, I962) it was found that the survival was greater in patients under 40 years of age at time of injury and with lower lesions. We have arrived at our percentages of survival by actual individual figures incorporating the factors of age, level, extent of lesions and survival times. This seems to us to be a more meaningful method than calculating an average survival time, as others did (Dietrich \& Russi, 1958; Tribe, 1963).

Comparative Figures. In comparing annual death rates of our traumatic spinal cord injury population over the last three years (I April 1962 to I April I965) with the figures published in the 8Ist year of issue of the World Almanac and Book of Facts for the population of the United States and that of California the following was found: the mortality percentage for the U.S.A. was 0.95 per cent., for California 0.83 per cent., and for our traumatic spinal cord population I 6 per cent. It should be remembered that the mortality figures for the U.S.A. 
and California contain a great number of women and children; the latter are completely absent in our figures.

Renal Mortality. We confirm the findings of others, namely, that renal death is still the leading cause. Damanski (I96I) found great variations of figures ranging from 12.5 per cent. to 78 per cent. when he divided the patients into two groups - those with adequate and those with inadequate management. Variations of renal mortality figures seem also to depend on the time at which the review was made. Thus, figures have been reported from this Centre of 31 per cent. (Bors, I954), 47 I per cent. (Nyquist, I960), 4I 6 per cent. (Nyquist, I965) and now we report 32.9 per cent. When one averages the percentages reported since 1943 (Barber \& Cross, I952; Bors, I954; Lord \& Bunts, I956; Damanski \& Gibbon, 1956; Dietrich \& Russi, I958; Nyquist, I960; Breithaupt et al., I96I; Damanski, I96I; Talbot, I962; Tribe, I963; Damanski, I963; Nyquist, I965; Dalton et al., 1965; Gibbon et al., I965), one arrives at a so-called average renal mortality percentage of $50 \cdot 2$ per cent.

The peaks of renal death in comparison to the number of survivors in groups arranged according to the level of injury and length of survival are shown in Table VIII, and are found chiefly in the second and third five-year post-traumatic periods. Similar observations have been made by Damanski (I96I). In comparing the subtotal percentages of renal mortality within the cervical and upper thoracic (TI to T6) groups (Table VIII), a higher mortality rate is found in the upper thoracic group ( 6 per cent.) than in the cervical group (3 per cent.). As both groups have in common the impairment of the splanchnic outflow, it seems that this impairment alone is not the only significant cause of renal death. It is a common clinical observation that decubitus ulcers are less frequent in patients with cervical cord lesions than in the other groups. Since decubiti are the most frequent cause of secondary amyloidosis, including the kidney, the relatively low incidence of renal deaths in the cervical groups may perhaps be explained on this basis. A similar trend seems also to apply to the lumbo-sacral group which has almost the same renal mortality rate as the cervical group in all five-year periods, with the exception of the third five-year period. Perhaps, here too, the same explantion may apply as in the cervical group.

Renal death with hypertension was recorded in seven patients $(8 \cdot 2$ per cent.), which is far lower than the observation of Tribe (I963) who considered it the major cause of death in 14.3 per cent., a contributory cause in 20.2 per cent. and no cause in 8 per cent. However, his total figures referring to I50 autopsies of traumatic and non-traumatic cases of cord lesions showed a still higher figure (43 per cent.) for hypertension.

Secondary Amyloidosis. Secondary amyloidosis was verified at necropsy in 24.2 per cent. of deaths. This is much less than is reported in the literature (Dietrich \& Russi, I958; Tribe, I963; Dalton et al., 1965). We believe that our figures do not accurately reflect the incidence of secondary amyloidosis as a cause of death because there are patients whose cause of death remained undetermined (I I per cent.) and because of all those who were not submitted to necropsy. Another source of error is that secondary amyloidosis may have been overlooked because it was not searched for, especially when autopsy was performed by the coroner. 
It would seem to us, in agreement with others (Comarr, I965; Dalton et al., I965), that the main source of secondary amyloidosis is provided by decubitus ulcers, rather than pyelonephritis, although Tribe (1963) has found in very rare instances secondary amyloidosis and pyelonephritis, but no decubitus ulcer. Tribe (1963) found secondary amyloidosis as the sole cause of death in 56.2 per cent., and he considered it to be a contributory cause in $29 \cdot \mathrm{I}$ per cent. Although our incidence of secondary amyloidosis is very small as compared with Tribe's figures (1963), the survival time of patients with secondary amyloidosis was similar to that of patients with renal failure; this is understandable considering that more than one half, 13, in our group died primarily of amyloidosis plus uraemia.

It is astounding that not more authors have paid attention to the subject of secondary amyloidosis from decubitus ulcers versus that from pyelonephritis.

Neither age at time of injury nor survival time was found to be correlated with the development of secondary amyloidosis as the main cause of death. Another negative observation was the fact that clinically diagnosed secondary amyloidosis did not permit a fair estimate of the probable length of survival.

Pulmonary Deaths. Pulmonary complications in our patients caused 6.9 per cent. of 258 deaths, a figure which is in the middle between 5.6 per cent. (Tribe, I963) and 8.5 per cent. (Breithaupt et al., 196I). We included paraplegics and tetraplegics, but $72 \cdot 2$ per cent. of these patients had cervical cord lesions. This reiterates the well-known respiratory morbidity of this group of patients.

Suicide. Overt suicide was the cause of $8 \cdot \mathrm{I}$ per cent. of our 258 deaths, and occurred in I. 3 per cent. of our paraplegic population. Rarely is this cause of death mentioned in the literature; 4 per cent. is reported by Damanski and Gibbon (1956). Of course, it is possible that suicidal death may be contained in the figures quoted for 'cause of death undetermined.' Our figure of $8 \cdot I$ per cent. does not include accidental deaths, undetermined deaths, nor the so-called 'physiologic suicide' deaths (Seymour \& Comarr, I956) resulting from self-neglect and chronic alcoholism, eventuating in decubitus ulcer, secondary amyloidosis, and cirrhosis. They would probably increase the number of suicidal deaths, but they are difficult to trace.

Our cases with 'physiological' suicide resemble somewhat the patients without spinal cord injury or disease, categorised by Jackson (1957) as 'partial' suicide characterised by multiple operations, accident proneness, etc., with one perhaps meaningful difference. Our patients usually direct their self-aggression upon parts of the body which have no pain perception, e.g., if they create decubitus ulcers in the anaesthetic area, they punish their 'bad' or 'dead' part of their body thus inducing eventual self-destruction.

In case of overt suicides all the motivations which apply to the non-paraplegic apply to our patients, such as loss of health, of self-esteem, socio-economic change, etc.

In comparing the age of our patients with overt suicide with that observed by Shneidman and Farberow (1957) in their non-paraplegic patients, a small difference appeared. The maximum number of our suicidal deaths occurred in the fourth decade. Shneidman's and Farberow's suicide-note writers (I957) 
were 99 in the third and fourth decades, 215 in the fifth and sixth decades and 175 in the seventh decade and up in males.

Age of our patients at suicide: I9 per cent. were in the third decade, 57 per cent. were in the fourth decade, I4 per cent. were in the fifth decade, Io per cent. were in the sixth decade. No suicide was observed past the age of 53. It is of incidental interest that the only patient who hanged himself had a diagnosis of pre-traumatic psychosis.

A rough estimate of our suicidal deaths in comparison with such deaths in the United States would suggest a double or even higher incidence among our patients than in the United States population (Bennett, 1957). On the other hand, even if one makes a generous allowance for the total number of suicides, overt and 'physiologic', one would still be far below the percentage of suicides as they occur in United States veterans afflicted with malignant neoplasia (MB9, V.A. Feb 25, I963) (I7 per cent.).

Although emotional factors enter the picture in both, myelopathy and neoplasia, two factors differ considerably; one is the relative paucity of pain in myelopathy and the other is the relative stability of myelopathy versus the progression of neoplasia. It is of interest that none of our traumatic myelopathy patients with neoplasia committed suicide.

Vascular Deaths. The discrepancy of our high figure io per cent. as compared with $7 \cdot 3$ per cent. (Dietrich \& Russi, 1958) or 14.9 per cent. (Breithaupt et al., I96I) can be explained by the difference of classification. As stated previously, our term of vascular death embraced such conditions as cardiac, cerebrovascular, pulmonary embolism, generalised arteriosclerosis, ruptured aneurysms, haemorrhage from decubitus ulcer and bacterial endocarditis; renal hypertension was not counted under this heading.

It may be of interest that Tribe (1963) found no pulmonary embolism in chronic paraplegia, only in 7 cases during the acute stage. Rossier and Brunner (I962) found mortality from pulmonary embolism during the first three months in 7 of 32 patients ( 22 per cent.). This motivated clinics in Switzerland and England to use prophylactic anticoagulant therapy. This observation of relatively high incidence of early fatal pulmonary embolism corresponds with the description of venous occlusion reported as I4 per cent. in 25 patients (Phillips, I963) or even as high as 58 in 99 patients (Bors et al., I954). Our incidence of pulmonary embolism has been relatively low although we do not use anticoagulant therapy. Six patients died from pulmonary embolism; three succumbed during the acute, and the other three patients during the chronic stage; one as late as 20 years after injury. We reiterate that relatively few of our patients are admitted during the acute stage; if they were, our incidence of early pulmonary embolism might be higher than the listed figure.

The total mortality from vascular conditions of $185 \mathrm{I}$ patients was 3 per cent. It is perhaps not unreasonable to presume that vascular deaths will increase with the extended life span of the paraplegia population.

Neoplasia. Our figure of 6.2 per cent. regarding death from malignant disease among 258 fatalities or 0.99 per cent. of I85I patients is somewhat higher than the figures of 4 per cent. (Damanski \& Gibbon, I956), 4.3 per cent. (Breithaupt et al., I96I) and $2 \cdot 8$ per cent. (Tribe, I963). 
Among those patients whose neoplasia was thought to be related to the injury were seven patients with cancers of the urinary tract and one patient with a cancer in a sacral decubitus ulcer; the latter is a rare observation (Gillis \& Lee, I95I; Tribe, I963; Guttmann, I965), if one considers the relatively high incidence of sacral decubiti. In this connection we have observed a second patient with a sacral decubital cancer who remained well up to date following surgical therapy in 1948 .

Per contra, the incidence of urinary tract cancer is appallingly high. In this study we found that one patient died from a renal clear cell carcinoma, five patients died from bladder cancer and one from urethral cancer. This means that death from urinary tract neoplasia occurred in 2.7 per cent. of all deaths or in 0.43 per cent. of all patients. In comparing this figure with the death incidence of 0.008 per cent. from urinary tract cancer in 196I (National Health Education Committee) among the population in the United States it shows that the urinary cancer death in traumatic paraplegia is 53 times greater than in the population of the United States.

Five of the seven patients with urinary tract cancers were catheter-free so that not the catheter but perhaps the chronic infection would provide a common denominator for the aetiology in our cases.

Six patients who died from urinary tract cancer were between 40 years and 50 years of age and the seventh patient was 32 years of age at the time of death. Deaths from cancer occurred within two years after diagnosis and within a period of from 12 to 20 years after injury.

Cardio-respiratory (Bulbar Involvement). This condition occurred in five patients with cervical or high thoracic lesions precipitated by ascending oedema; it was observed in 2.3 per cent. of 258 deaths or 0.32 per cent. of I85I traumatic patients. Damanski and Gibbon (1956) described one case (4 per cent.) of 25 deaths as due to 'ascending palsy'. Tribe (1963) found respiratory death in 8 of 16 acute cases of paraplegia ( 50 per cent.); all eight patients had cervical cord lesions. It is possible that the death rate of tetraplegics within the first year which has been reported by Burke et al. (I960) as three times that of paraplegics is in part caused by this condition, although this has not been specified in their paper. Direct extension of arachnoiditis-as was the case in our sixth patientmust be differentiated from remote late lesions and cyst formation described recently by Barnett et al. (1966).

Accidental Deaths. This was found in I2 patients, 4.6 per cent. of 258 deaths, or 0.73 per cent. of I 85 I patients. Breithaupt et al. (I96I) found I I per cent. accidental deaths, while Lord and Bunts (I956) reported 20 per cent. of 'violent' deaths. No further description is offered regarding the 'violence' so that inclusion of suicides in this figure is not impossible. In IO of our I2 patients suicide can be absolutely excluded. Car accidents play a major role ( 75 per cent.) as a cause of accidental death in our patients.

Iatrogenic Causes. Iatrogenic causes of death could be subdivided into diagnostic and therapeutic errors of judgment. Out of 8 (3.I per cent. of 258 deaths or 0.42 per cent. of I85I traumatic patients) 3 can be ascribed to diagnostic misjudgment (Nos. I, 2, and 4) and 3 to therapeutic errors (Nos. 6, 7, and 8). 
The latter contain the following variations: failure to choose the proper type of operation by misleading X-ray and gross findings (No. 8), failure to intervene in time (No. 6) and error in surgical technique (No. 7).

In two patients neither an error of diagnosis nor therapy can be blamed (Nos. 3 and 5). These patients had insufficient resistance to recover.

Although it is possible, it is at times difficult to make the diagnosis of a perforated viscus in patients with high thoracic or cervical cord lesions. Among the leading symptoms and signs are: acute shoulder pain, nausea and vomiting, increased abdominal and skeletal spasticity and free gas in the abdominal cavity visible in $\mathrm{X}$-ray studies. Skeletal spasticity-when known to the observer from previous examinations-may revert from normally present extensor to flexor spasticity.

In patients with traumatic paraplegia below the splanchnic outflow, diagnosis of an abdominal catastrophe follows-with some restrictions-according to the level, more or less the known pattern of patients with a normal neuraxis.

Dietrich and Russi (1958) and Breithaupt et al. (I96I) have reported 10.9 per cent. and I.I per cent. of deaths, respectively, which we might have called iatrogenic. Watkins (1954) reported one case of iatrogenic death due to undiagnosed diaphragmatic hernia of Io months' duration.

Hepatic Death. Liver disease other than neoplasm was the cause of $2 \cdot 3$ per cent. of 258 deaths or 0.32 per cent. of I851 paraplegic patients. Dietrich and Russi (1958) mentioned I4.5 per cent. hepatic deaths, while Tribe (1963) found altogether 3 deaths in 150 necropsies ( 2 per cent.) which concerned traumatic and non-traumatic paraplegia. He considered all of his cases unrelated to the spinal cord condition. Contrary to Tribe (1963) we felt that the deaths of all six of our patients were related to the spinal cord injury, including two cases of cirrhosis for which an indirect relationship could be postulated. The remaining four cases of hepatitis following blood transfusion or chlorpromazine medication are undoubtedly directly related.

The death rate from blood transfusions is I.I6 per cent. ( 3 in 258 deaths). Considering that of the I 593 living and 258 dead traumatic paraplegics everyone has received blood transfusions at one time or another, the figure of transfusion deaths changes to 0.16 per cent. when calculated on the basis of I85I patients. In addition, multiple transfusions are being used in these patients which further depresses the proability of a deleterious effect.

Hepatic pathology (amyloidosis, periportal cirrhosis, fatty metamorphosis, acute hepatitis, hepatic biliary duct lithiasis) was found in 28 of 55 necropsies (50.9 per cent.) by Caravati et al. (1958).

Miscellaneous Deaths. Our miscellaneous deaths could have been also labelled deaths from neurological complications because all of the four patients showed symptoms, signs and necropsy findings pertaining to this category. The incidence was small, I.55 per cent. of 258 deaths, or 0.21 per cent. of I85I patients.

Undetermined Deaths. This concerned 28 patients, I0.8 per cent. of 258 deaths, or I.47 per cent. of I85I patients. Breithaupt et al. (I96I) listed 6.4 per cent. of deaths as undetermined. 


\section{SUMMARY}

Among 20I I patients treated on the Spinal Cord Injury Service the mortality was 304 (I5 per cent.).

The mortality among I85I patients with traumatic paraplegia was 258 (13.9 per cent.), which has been analysed in detail.

Of 258 deaths, I72 (67 per cent.) were related and 58 ( 22 per cent.) were unrelated to the injury; 28 deaths (I I per cent.) remained undetermined as to relationship with spinal cord injury.

The corrected mortality among I85I patients with traumatic paraplegia was 200 (I0.8 per cent.).

The mortality of I60 patients with non-traumatic paraplegia was 46 (29 per cent.).

The uncorrected mortality among I85I patients with traumatic paraplegia was highest, 16.5 per cent., in the group with lower thoracic lesions ( $\mathrm{T}_{7}$ to $\mathrm{I}_{2}$ ); next the upper thoracic group (TI to 6), I3.5 per cent. ; next the cervical lesions, I2.4 per cent.; and lastly, the lumbo-sacral lesions, I I 4 per cent.

The uncorrected mortality among patients (564) with cervical lesions was I2.4 per cent., that of all remaining patients (I287) was I 4.5 per cent.

Age at injury played a greater role than level and extent of injury regarding the average survival time not only among the deceased, but also among the still living patients.

Of the original group of I80 patients on I April I946, I32 patients are still alive, i.e., 73 per cent. have survived 20 years or more. Of I 593 living patients with traumatic paraplegia, 379 (23.8 per cent.) have survived 20 years or more, and 1002 (62.9 per cent.) have survived Io to I9 years.

The annual death rate from 1962 to 1965 was I.6 per cent. among our patients as compared to 0.95 per cent. for the U.S.A. and 0.83 per cent. for California.

Renal failure was the most frequent cause of death, namely, 85 of 258 deaths (32.9 per cent.); renal failure plus amyloidosis occurred in I3 (15.2 per cent.), and renal failure with hypertension in $7(8.2$ per cent.) cases. Of the $185 \mathrm{I}$ traumatic paraplegic patients, 5 per cent. have died from renal failure. Renal failure was more frequent with thoracic than other levels.

If a patient survives I5 years without serious renal complications, the probability of renal death declines.

Secondary amyloidosis was the cause of 24 of 99 necropsies $(24 \cdot 2$ per cent.) or of 258 deaths ( 9.6 per cent.) or approximately 2 per cent. of I 85 I patients with traumatic paraplegia. Amyloidosis was more frequent with thoracic than other levels. The survival time of patients with amyloidosis resembled that of patients with renal failure.

Pulmonary complications caused I 8 of 258 deaths $(6.9$ per cent.) or 0.9 per cent. of I85I patients with traumatic paraplegia. Of the I 8 deaths, $13(72 \cdot 2$ per cent.) occurred in patients with cervical cord lesions.

Overt suicide was the cause of $2 \mathrm{I}$ of 258 deaths (8. I per cent.) or I 3 per cent. of all patients with traumatic paraplegia. Suicide could not be related to either the age of the patient or the level of injury. Drugs and gunshot wounds were the foremost among causes of suicide.

Vascular conditions, including cardiac, cerebrovascular, pulmonary embolism 
generalised arteriosclerosis, ruptured aneurysm, haemorrhage and bacterial endocarditis, caused 49 of 258 deaths (I9 per cent.) or 3 per cent. of I85I patients. Only $6(2 \cdot 3$ per cent.) of all deaths or 0.3 per cent. of all patients died of pulmonary embolism, a remarkably low figure considering that venous occlusions of the lower extremities are frequent among patients with spinal cord injuries. One half of these 6 fatal embolisms occurred early (within I to 2 months after injury), the other half late from 7.5 to 20 years after injury.

Cardiovascular causes numbered 23 (47 per cent.) of all vascular deaths, i.e., 8.9 per cent. of 258 deaths or $\mathrm{I} \cdot 2$ per cent. deaths of $185 \mathrm{I}$ patients with traumatic paraplegia.

Neoplasia caused 16 of 258 deaths $(6.2$ per cent.) or 0.99 per cent. of all patients. Eight were unrelated, the other eight were related to the injury including seven who died of urinary tract cancer. This latter incidence is 53 times that of the U.S.A. population. Chronic infection is perhaps the common denominator for the development of urinary tract cancer.

Cardio-respiratory failure from bulbar involvement caused 6 of 258 deaths $(2.3$ per cent.) or 0.32 per cent. of I85I patients with traumatic paraplegia. This type of death occurred acutely within the first two months in 5 of the 6 patients. Only in one did progression of arachnoiditis lead to myelomalacia 20 years after injury.

Accidents caused 12 of 258 deaths ( 4.6 per cent.) or 0.73 per cent. of I $85 \mathrm{I}$ traumatic paraplegics.

Iatrogenic, diagnostic or therapeutic, misjudgment caused 8 of 258 deaths (3. I per cent.) or 0.42 per cent. of I85I traumatic paraplegics. In all instances abdominal conditions were the cause for misjudgment. The cases of these 8 patients are reported in detail.

Hepatic conditions caused 6 of 258 deaths $(2.3$ per cent.) or 0.32 per cent. of I85I traumatic paraplegics.

Miscellaneous conditions (epidural spinal abscess with meningitis, cerebral abscess, convulsive reaction following intracaine injection, progressive muscular atrophy) caused 4 of 258 deaths (I 55 per cent.) or 0.2 I per cent. of I85I traumatic paraplegics.

The cause of death remained undetermined in 28 of 258 deaths (I I per cent.) or I.47 per cent. of I85I traumatic paraplegics.

The findings are discussed in the light of the literature.

\section{RÉSUMÉ I}

Sur 20II malades traités au Centre de Traumatologie de la Moelle Epinière de Long Beach, la mortalité totale a été de 304 (15\%), sur 1851 paraplégiques traumatiques, la mortalité a porté sur 258 (13,9\%) dont les cas ont été analysés en détail.

La paraplégie elle-même a été responsable de la léthalité dans 172 cas (67\%). $58(22 \%)$ sont morts de causes autres. Il n'a pas été possible de déterminer avec exactitude une relation entre la mort et l'atteinte spinale sur 28 cas (II \%).

La mortalité corrigée parmi I85I cas avec paraplégie traumatique a été de 200 (I0, 8\%). Celle portant sur I60 malades avec paraplégie non traumatique a été de $46(29 \%)$. La mortalité non corrigée parmi $185 \mathrm{I}$ malades avec une paraplégie traumatique a été la plus élevée, I $6,5 \%$ dans le groupe avec une lésion thoracique basse ( $\mathrm{D}_{7}$ à DI2) ensuite, dans le groupe des atteintes thoraciques hautes (DI à D6), I3,5\%; les lésions cervicales $12,5 \%$; 
et enfin, les lésions lombosacrées, I I,4\%. La mortalité non corrigée parmi 564 malades avec une lésion cervicale a été de I2,4\%, cells des autres malades, I 287 , de $14,5 \%$.

L'âge, au moment de la lésion, a joué un plus grand rôle que le niveau et l'importance de celle-ci en ce qui concerne la durée moyenne de survie, non seulement parmi les décédés, mais aussi parmi ceux qui sont toujours en vie.

Du premier groupe de I80 malades detant du ler avril I946, I32 sont toujours vivants, c'est-à-dire que $73 \%$ ont survécu au cours des 20 , ou plus, dernières années. Des I 593 survivants avec paraplégie traumatique, $379(23,8 \%)$ ont survécu 20 ans, ou plus, et 1002 $(62,9 \%)$ de Io à I9 ans.

Le taux de mortalité annuel de 1962 à I 965 était de I,6\% parmi nos malades, comparés à $0,95 \%$ pour les Etats Unis et $0,83 \%$ pour la Californie.

L'insuffisance rénale terminale a été la cause la plus fréquente de mortalité, 85 des 258 morts $(32,9 \%)$; l'insuffisance rénale plus la dégénérescence amyloîde est survenue dans $I_{3}(15,2 \%)$ et l'insuffisance rénale avec hypertension dans $7(8,2 \%)$ cas. Des I $85 \mathrm{I}$ cas de paraplégie traumatique, $5 \%$ sont morts d'insuffisance rénale, celle-ci étant plus fréquente dans les lésions thoraciques qu'aux autres niveaux.

Si un malade survit les I5 premières annés sans complications rénales sérieuses, la probabilité d'une mort dûe à cette affection décline.

L'amylose secondaire a été la cause déclenchante dans 24 nécropsies ou $99(24,2 \%)$ ou $9,6 \%$ des décès, approximativement $2 \%$ des I 85 I léthalités avec paraplégie traumatique. Cette affection a été plus fréquente avec les lésions thoraciques qu'un autre niveau. Le temps de survie du malade présentant ces complications est semblable à celle des malades avec une insuffisance rénale.

Les complications pulmonaires ont provoqué 18 des 258 morts $(6,9 \%)$ ou $0,9 \%$ des I85I malades avec paraplégie traumatique. Sur ces I8 cas, I3 $(72,2 \%)$ sont survenus chez des malades porteurs d'une lésion cervicale.

Le suicide a été la cause de $2 \mathrm{I}$ morts sur $258(8, \mathrm{I} \%)$ ou I, $3 \%$ du total avec atteinte traumatique. Cette cause n'a pas pu être mise en relation avec l'âge ou le niveau de la lésion. Les suicides par médicaments ou armes à feu étaient les plus nombreux.

Les complications vasculaires, cardiaques, cérébrales, l'embolie pulmonaire, l'artériosclérose généralisée, les ruptures d'anévrisme, l'hémorragie, l'endocardite bactérielle ont provoqué 49 des 258 morts (19\%) soit 36 des I 85 I malades. Seulement $6(2,3 \%)$ de toutes les morts $(0,3 \%)$ ont été provoquées par une embolie pulmonaire, ce qui est un chiffre extrêmement bas, considérant que l'occlusion veineuse des membres inférieurs est fréquente parmi les malades présentant une atteinte spinale.

La moitié de ces embolies fatales sont survenues tôt (entre I et 2 mois après la lésion initiale), l'autre moitié entre 7,5 et 20 ans après celle-ci.

Les causes cardio-vasculaires se montent à $23(47 \%)$ de toutes les morts vasculaires, c'est-à-dire $8,9 \% 258$ malades ou $1,2 \%$ sur les $185 \mathrm{I}$ paraplégies traumatiques.

Les néoplasmes ont provoqué I6 des 258 morts $(6,2 \%)$ ou $0,99 \%$ de tous les malades. 8 n'avaient pas de relations avec la paraplégie, les 8 autres morts ont pu être mises en rapport avec l'atteinte médullaire dont 7 d'entre elles de cancer des voies urinaires. Cette incidence est de 53 fois plus élevée que celle observée parmi la population des U.S.A. L'infection chronique est probablement le dénominateur commun de ces cancers urinaires.

La défaillance cardio-respiratoire dûe à une atteinte bulbaire a été la cause de 6 sur 258 morts $(2,3 \%)$ ou $0,32 \%$ sur I 85 I malades avec paraplégie traumatique. Cette complication léthale est survenue au cours de la phase aiguë pendant les 2 premiers mois sur 5 des 6 malades. Une arachnoîdite progressive provoquant un ramollisement médullaire 20 ans après la lésion dans le dernier cas.

Des accidents ont causé I 2 morts sur $258(4,6 \%)$ ou $0,73 \%$ des I 85 I cas traumatiques. Les erreurs de diagnostic, ou de thérapeutique ont causé 8 des 258 morts $(3,1 \%)$ ou 0,42 des I85I cas. Dans tous les cas, des complications abdominales ont été la cause d'erreur. Celles-ci ont été rapportées sur 8 malades.

L'atteinte hépatique a causé 6 des 258 morts $(2,3 \%)$ ou $0,32 \%$ des 1851 cas.

Les conditions diverses (abcès épidural avec méningite, abcès cérébral, réaction convulsive après injection d'intracaîne, atrophie musculaire progressive) ont causé 4 des 258 morts $(\mathrm{I}, 55 \%$ ) ou $0,2 \mathrm{I} \%$ des $\mathrm{I} 85 \mathrm{I}$ cas traumatiques.

La cause de mort demeure indéterminée dans 28 des 258 (II \%) ou I, 47\% des $185 \mathrm{I}$ cas traités.

Les résultats ont été discutés à la lumière de la littérature.

D 


\section{ZUSAMMENFASSUNG}

Von 20I I Patienten, die im Spinal Cord Injury Service, Long Beach, Cal. behandelt wurden, starben 304 (15\%).

Von I85I Patienten mit traumatischer Paraplegie starben 258 (13.9\%), deren Todesursachen im Einzelnen analysiert wurden.

Die Ursache des Todes war unter 258 Fällen in $172(67 \%)$ auf den Unfall zurückzuführen, in $58(22 \%)$ bestand kein Zusammenhang; in 28 Fällen (1 I \%) konnte ein Zusammenhang zwischen Rückenmarksverletzung und Todesursache nicht mit Sicherheit bestimmt werden.

Die Zahl der als direkte Unfallsfolge anzusehenden Todesfälle nach Rückenmarksverletzung betrug $200(10.8 \%)$ unter I 85 I traumatischen Paraplegikern. $(29 \%)$.

Die Sterblichkeit bei I60 Patienten mit nicht unfallbedingter Paraplegie betrug 46

Unter den I85I Patienten mit traumatischer Paraplegie-ohne Berücksichtigung des Zusammenhanges der Todesursache mit dem Unfall-war die Mortalität am höchsten (16.5\%) in der Gruppe der unteren Dorsalläsionen (D7-12); es folgte die Gruppe der höheren dorsalen (DI-6) mit $13.5 \%$, dann die Zervikalläsionen, $12.4 \%$ und schliesslich die Lumbosakralläsionen mit I I $4 \%$.

Die totale Mortalität bei 564 Patienten mit Zervikalläsionen war $12.4 \%$, bei den übrigen $1287 \mathrm{I} 4.5 \%$.

Das Alter zur Zeit der Verletzung spielte eine grössere Rolle als das Niveau und die Ausdehnung der Lähmung für die durchschnittliche Lebensdauer nicht nur der Verstorbenen, sondern auch der noch lebeden Patienten.

Von den am I April I 946 lebenden I 80 Patienten, sind noch 132 am Leben, das heisst, dass $73 \% 20$ oder mehr Jahre den Unfall überlebt haben. Von I 593 überlebenden Patienten mit traumatischer Paraplegie haben $379(23.8 \%)$ jetzt 20 oder mehr Jahre überlebt. IOO2 Patienten $(62 \cdot 9 \%)$ leben IO-I9 Jahre nach der Verletzung.

Die jährliche Todesrate-von I 962-65-war I $6 \%$ für unsere Paraplegiker verglichen mit $0.95 \%$ in der Allgemeinbevölkerung der U.S.A. und mit $0.83 \%$ in Kalifornien. Versagen der Nieren war die häufigste Todesursache, bei 85 von 258 Todesfällen $(32 \cdot 9 \%)$. Niereninsuffizienz mit Amyloidose trat bei I3 Patienten (15.2\%) auf, mit Hochdruck bei $7(8.2 \%)$. Von allen I85I traumatischen Fällen starben $5 \%$ an Niereninsuffizienz, die häufiger bei Dorsalläsionen als bei anderen Niveaus gefunden wurde.

Wenn ein Patient I5 Jahre lang ohne ernsthafte Nierenkomplikationen überlebt, fällt die Wahrscheinlichkeit, dass er an Niereninsuffizienz sterben wird.

Sekundäre Amyloidose war die Ursache bei 99 Obduktionen $(24.2 \%)$ oder bei 258 Todesfällen $(9.6 \%)$ oder etwa $2 \%$ von I85I Patienten mit traumatischer Paraplegie. Amyloidosis war häufiger bei Dorsalläsionen als bei anderen Niveaus. Die Überlebensdauer der Patienten mit Amyloidose war etwa dieselbe wie derer mit Niereninsuffizienz.

Lungenkomplikationen waren für I8 unter 258 Todesfällen $(6.9 \%)$ oder $0.9 \%$ von I85I Patienten verantwortlich. Unter den I8 Todesfällen betrafen I3 $(72 \cdot 2 \%)$ Patienten mit Zervikal-Läsionen.

Eindeutiger Selbstmord war für 2I unter 258 Todesfällen $(8 \cdot I \%)$ verantwortlich, d.h. für $\mathrm{I} \cdot 3 \%$ aller Patienten mit traumatischer Paraplegie. Er stand in keiner festen Beziehung zu Lebensalter oder Niveau der Lähmung. Medikamente und Schusswaffen waren die häufigsten Mittel.

Gefässerkrankungen-Herz-, Hirngefässe, Lungenembolie, Arteriosklerose, Ruptur eines Aneurysmas, Blutung und bakterielle Endokarditis-waren die Todesursache bei 49 unter 258 Fällen (19\%) oder bei 3\% aller I05I Patienten. Nur $6(2 \cdot 3 \%)$ aller Todesfälle oder $0.3 \%$ aller Patienten starben an Lungenembolie, eine bemerkenswert niedrige Zahl, wenn man bedenkt, dass Thrombosen der Beinvenen bei Rückenmarksverletzten häufig sind. Die Hälfte dieser 6 tödlichen Embolien traten früh auf (I-2 Monate nach dem Unfall), die anderen 3 Fälle 7.5 bis 2 Jahre nach der Verletzung.

Herz-und Gefässerkrankungen waren für $23(47 \%)$ aller vaskulären Todesfälle verantwortlich, d.h. $8 \cdot 5 \%$ aller 258 Todesfälle oder für $3 \cdot 2$ Todesfälle unter den I85I Patienten mit traumatischer Paraplegie.

Neoplasmen waren für I6 $(6.2 \%)$ von 258 Todesfällen oder $0.99 \%$ aller Patienten verantwortlich. 8 standen in keiner Beziehung zu der Verletzung, die anderen 8 standen 
im Zusammenhang mit ihr, davon 7 mit Krebs im Harntrakt. Dies entspricht einer 53 mal grösseren Häufigkeit als der der Allgemeinbevölkerung der U.S.A. Chronische Infektion ist wahrscheinlich die gemeinsame Ursache für die Krebsentwicklung im Harntrakt. Versagen des Kreislaufs und der Atmung durch Einbeziehung bulbärer Zentren führte 6 mal bei 258 Todesfällen $(2 \cdot 3 \%)$ zum Tode oder bei $0.32 \%$ von I 85 I traumatischen Paraplegikern. Dieser Typus des Todes trat plötzlich innerhalb der ersten 2 Monate bei 5 von diesen 6 Patienten auf. Nur einmal führte progressive Arachnoiditis und Myelomalacie zum Tode nach 20 Jahren.

Unfälle verursachten I2 von 258 Todesfällen $(4.6 \%)$ oder $0.73 \%$ von I85I traumatischen Paraplegien. Ärztliche Fehler, diagnostisch oder therapeutisch, waren für 8 unter 258 Todesfällen $(3.1 \%)$ oder $0.42 \%$ von I85I Querschnittsgelähmten verantwortlich. In allen Fällen waren es Irrtümer in der Diagnose und Therapie intra-abdominaler Vorgänge. Diese $8 \mathrm{~F}$ älle werden im Einzelnen beschrieben.

Lebererkrankungen verursachten 6 von 258 Todesfällen $(2 \cdot 3 \%)$ oder $0.32 \%$ von I85I traumatischen Paraplegikern. Eine Mischgruppe (epiduraler Abszess mit Meningitis, Cerebraler Abszess, epileptoide Reaktion nach Intracain Injektion, progressive muskuläre Atrophie) verursachte 4 Todesfälle unter 258 (I.55\%) oder $0.2 \mathrm{I} \%$ von I85I traumatischen Paraplegien.

Die Todesursache blieb ungeklärt in 28 unter 258 Fällen (II \%) oder I $47 \%$ von I85I Patienten.

Die Resultate werden gegen den Hintergrund der Literatur diskutiert.

\section{REFERENCES}

BARBeR, K. E. \& Cross, R. R. Jr. (1952). F. Urol. 67, 494.

BARnetT, H. I. M., Botterell, E. H., Jousse, A. T. \& WynN-Jones, M. (I966). Brain, 89, I59.

Bennett, A. E. (I957). Clues to Suicide, p. I87. New York: McGraw-Hill Book Co., Inc. Bors, E. (1954). F. int. Coll. Surg. 21 , 513.

Bors, E., ConRad, C. A. \& MAssell, T. B. (1954). Surgery Gynec. Obstet. 99, 45 I.

Breithaupt, D. J., Jousse, A. T. \& Wynn-Jones, M. (I96I). Can. med. Ass. F. 85, 73.

Burke, M. H., Hicks, A. F., Robins, M. \& Kessler, H. (I960). F. Am. med. Ass. I72, I2 I.

Caravati, C. M., Morey, A. J. \& Regan, W. W. (I958). Gastroenterology, 34, 683.

Comarr, A. E. (1954). Proceedings of 3 rd Annual Clinical Paraplegia Conference, Veterans Administration, West Roxbury, Mass., p. I8.

Cook, E. N. (1942). Proc. Staff Meet. Mayo Clin. 17, 564.

Dalton, J. J., HaCkler, R. H. \& Bunts, R. C. (1965). F. Urol. 93, 553.

DAMANSKI, M. \& GIBSON, N. O. K. (I956). Br. F. Urol. 28, 24.

DAMANSKI, M. (I96I). Br. F. Urol. 33, 400.

DAMANSKI, M. (I963). F. Urol. 89, 660.

DICK, T. B. S. (I952). Br. F. Urol. 24, IOI.

Dietrich, R. B. \& Russi, S. (I958). Э. Am. med. Ass. 166, 4 I.

Gibbon, N. O. K., Ross, J. C. \& Damanski, M. (1965). Paraplegia, 2, 264.

Gillis, L. \& LeE, S. (I95I). F. Bone ft Surg. 33B, I67.

GutTMAnN, L. (1956). Br. F. plast. Surg. 8, I 96.

Guttmann, L. (1962). Monthly Bulletin of the Ministry of Health and the Public Health Laboratory Service, $\mathbf{2 1}, 60$.

Guttmann, L. (1965). Personal communication.

HARDY, A. G. (1956). Br. F. Urol. 28, 53.

Hemingway, A., Bors, E. \& HobBs, R. P. (1958). F. clin. Invest. 37, 773.

JACKson, D. D. (1957). Clues to Suicide, p. 42. New York: McGraw-Hill Book Co., Inc. LORD, K. H. \& BUNTS, C. R. (1956). F. Urol. 75, 66-72.

Medical Bulletin 9 (I963). Dept. Med. and Surg., Vet. Adm., Washington, D.C., p. I. National Health Education Committee, Inc. (I96I). Facts on Major Diseases, p. 4.

NyQuIST, R. H. (1960). Proceedings of the Ninth Annual Clinical Spinal Cord Injury Conference, Vet. Adm. Hosp., Long Beach, Calif., p. Io9.

Nyquist, R. H. (I965). Calif. Med. ro3, 4I7-4I9.

Partsch, F. \& Wagner, L. (I949). Medsche Klin. 44, 203-206. 
Phillips, R. S. (1963). Paraplegia, I, II6.

Rossier, A. \& BrUNNER, V. (I964). Schweiz. med. Wschr. 94, 362.

Seymour, C. T. \& Comarr, A. E. (1956). Am. f. Surg. 91, 849.

Shneidman, E. S. \& Farberow, N. L. (1957). Clues to Suicide, p. 42. New York: McGrawHill Book Co., Inc.

Talbot, H. S. (I962). 87th Congress, 2nd Session, House Committee Print No. 259, U.S. Gov. Printing Office, Wash. D.C., p. I.

Tribe, C. R. (1963). Paraplegia, I, I9.

Watkins, A. L. (I954). Arch. phys. med. Rehabit. 35, 369.

World Almanac AND Book of FACts (1966). N.Y. World-Telegram and the Sun, 81st yr. of issue, p. 298. 